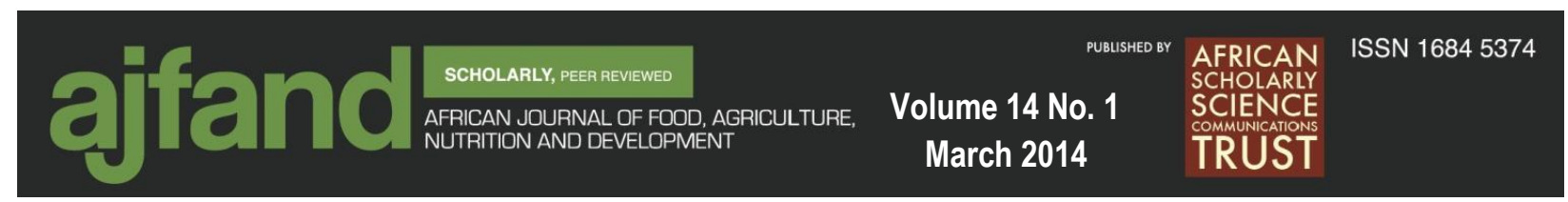

\title{
APPLICATION OF THE FLOUR OF FOUR LEGUMINOUS CROPS FOR THE CONTROL OF TENEBRIONIDAE BEETLE (TRIBOLIUM CASTANEUM - HERBST)
}

Tamgno BR $^{1,2^{*}}$ and SL Ngamo Tinkeu ${ }^{2}$

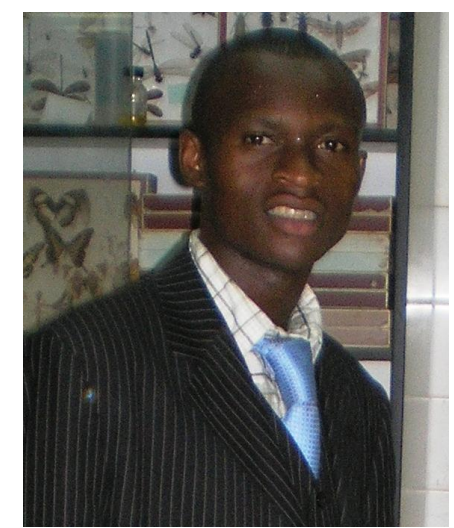

Béranger Raoul Tamgno

*Corresponding author email: tamgnoberanger@gmail.com

${ }^{1}$ Institute of Fisheries and Aquatic Sciences, University of Douala, P.O. Box 7236, Douala-Cameroon

${ }^{2}$ The Department of Biological Sciences, Faculty of Science, University of Ngaoundéré, P.O. Box 454, Ngaoundéré-Cameroon. 


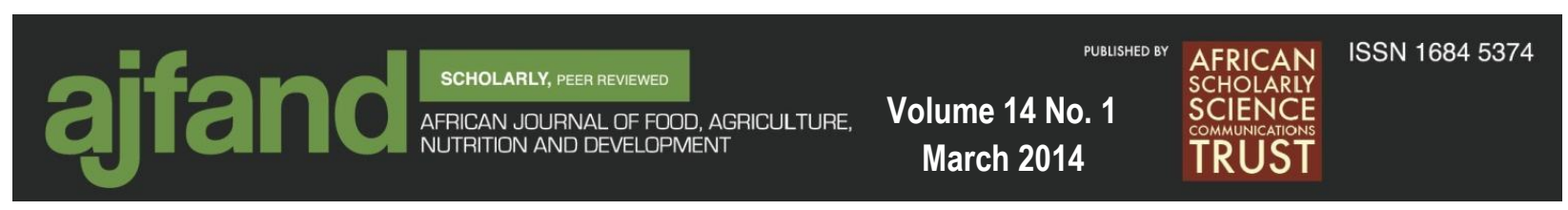

\begin{abstract}
Provender used to breed animals is constituted mainly of cereal flour. However, due to poor post-harvest technologies, more than $35 \%$ of annual crop yield is often lost during storage as a consequence of insect attack. While synthetic insecticides constitute an efficient method for reducing these losses; current excessive usage runs the risk of increasing the food insecurity. The use of entomotoxic proteins of leguminous plant for grain storage has been advocated as an alternative method with limited or no effect on the quality and safety of the grains or their products. This study was carried out as an evidence of bioactivity of four flours of seeds of Phaseolus vulgaris, Pisum sativum and two varieties of Glycine max (SJ320 and DOCKO) against adults of Tribolium castaneum Herbst which is a very resistant stored product pest to chemicals in Northern Cameroon. The growth of ten couples of $T$. castaneum in different formulations made by the mixture of sorghum flours with leguminous seed flours is evaluated 50 days after application. The research carried out reveals that the population of $T$. castaneum is important in the soybean formulations. In the pots of bean and pea flours, the average numbers of living pests were respectively $21.17 \pm 10.5$ and $32.38 \pm 18.3$ against $65.99 \pm 28.1$ and $95.2 \pm 36.7$ for the pots containing soybean SJ320 and DOCKO flours, respectively. In treatments PP20 and BB20, the number of nymphs $82.4 \pm 6.7,86.6 \pm 2.7$, respectively and the larvae V 22.2 \pm 9.9 , $68.8 \pm 8.9$ in that order decreases comparatively to the control $143.6 \pm 7.4,142 \pm 12.5$, respectively. The incorporation of these promising flours of pea and bean at a rate of $20 \%$ during manufacturer of provender used to feed animals can contribute to their better cereal food conservation and can reduce the residues of chemical pesticides in the environment. The formulation with $20 \%$ of black beans or pea flours in sorghum flour ensures an effective control of $T$. castaneum. The development of a bio insecticide made of flour of pea or black bean is to be considered seriously since their residues are not poisonous to consumers. Cereals which are important and indispensable for the production of animal feed can be preserved from insect attack by the use of natural products, which will contribute to diminish the toxicity of chemical preservatives used in feed, environmental pollution and the phenomenon of resistance of insects to chemical pesticides.
\end{abstract}

Key words: Entomotoxic proteins, Tribolium castaneum, Stored, Provender 


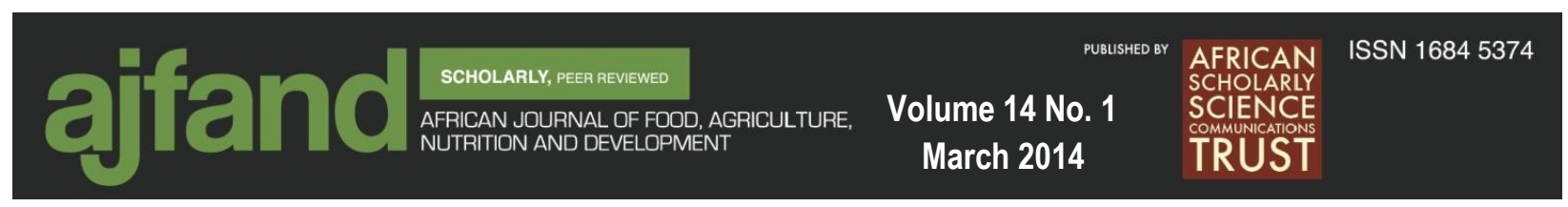

\section{INTRODUCTION}

Insects are the major pests of cereals grain or flour during storage. Damage due to insects affects the quality, the quantity, the commercial and agronomic value of the products. Many pests of stored products are Coleopterans and the most destructive tropical species for cereals belong to the genus Sitophilus and Tribolium [1]. Damage due to pest of the genus Tribolium on flours or other cereal processed products, are mostly impurities and stains which would be capable of poisoning consumers [2]. The excrements and other exudations from the larvae of this pest contaminate the food which tends to smell and thus lose their commercial or nutritional value [3]. This bad smell is accentuated by the nauseous pheromones produced by the adult beetles [4]. The control of pests in stored products, principally cereal grains, by the application of chemicals which is a common strategy for post-harvest loss avoidance, had led to the occurrence of many problems like the pollution of environment, toxicity to human being, emergence of resistant pests strains and many others damages [5, 6]. These synthetic pesticides are expensive for the small-scale farmers and pose potential risks due to the lack of technical knowledge on their safe use.

Due to the undesirable effects of chemical insecticides on the environment, human health and useful organisms, recent researches have been undertaken in order to minimize the agro-environmental pollution and health hazards caused by them and to replace them with other methods. Hence, there is need to explore new effective biological pests control methods which can confer protection to crops against insect pests $[7,8,9,10]$. The most efficient crop protection method nowadays must be one which employs a consumer- and environmentally-friendly approach. Among the recent methods, biological methods are one of those which offer ecological solutions that respect the environment [11]. The bacterial proteins which are widely used and sold as biological insecticides since 1950 was the first effort for this purpose [12]. Other supplemental methods, including the use of entomotoxic proteins were introduced in crop protection; due to resistance of some insect pests to repeated $\mathrm{Bt}$ toxin applications and none affected Homopterans pests by Bt toxins $[13,14,15,16$, 17].

The use of protecting materials which are edible by human and other animals may be a good alternative in pest control. In this context, the development of a new approach for the protection of stored food stuff based on the use of the natural and edible food substances such as leguminous plants containing entomotoxic proteins would reduce considerably the environmental risks associated with the use of these phytosanitory materials for protection [18]. Leguminous plants have many entomotoxic proteins like lectins which have the insecticidal activity towards many insect taxa such as Coleoptera, Lepidoptera and Homoptera [8, 18, 19]. Generally, these entomotoxic factors are introduced in the genome of cereals to confer on them the resistance to some insect pests; but many cases of resistance have been mentioned [14, 15, 17]. The process of introducing entomotoxic factors in the genome of plant is also expensive considering the cost of seeds. 


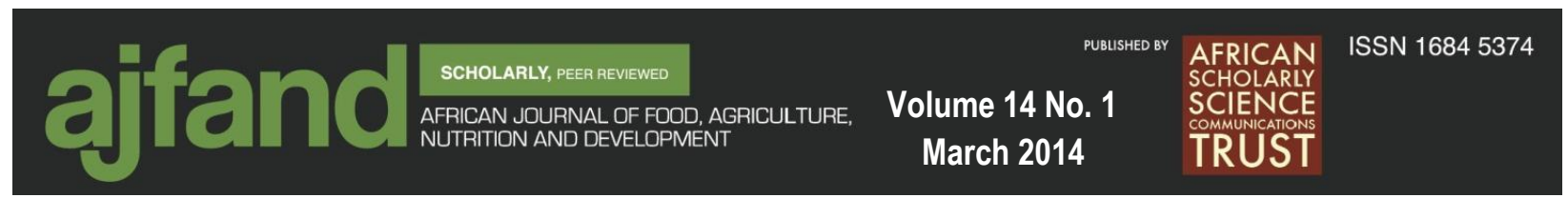

The objective of this study was to determine directly the differences in the insecticidal properties of four leguminous flours from seeds of Phaseolus vulgaris L. (Fabaceae), Pisum sativum L. (Fabaceae) and Glycine max L. (Fabaceae) on young adults of Tribolium castaneum Herbst (Coleoptera: Curculionidae).

\section{MATERIALS AND METHODS}

Tests were carried out to compare the insecticidal efficacy of 4 leguminous food plants on the young adults of T. castaneum reared on sorghum flour. The two varieties of soybean Glycine max SJ320 (SJ) and DOCKO (DK) were obtained from the Wakwa Agricultural Institute of Research for Development in Adamawa-Cameroon, the variety of bean Phaseolus vulgaris little black (BB) coming from Bandjoun in West-Cameroon and the pea Pisum sativum (PP) were bought at Ngaoundéré in Adamaoua-Cameroon.

\section{Preparation of the flour of seeds of Leguminous crops}

The seeds of little black bean (BB), of pea (PP) and of two varieties of soybean (SJ and DK) were reduced to flour in the Laboratory of Entomological Researches at the University of Ngaoundéré. For each of 4 studied plants, $2000 \mathrm{~g}$ have been ground using a mill, type WARRING BLENDOR to obtain the flour. The flours obtained were sifted using a sieve, type RETSCH GmbH \& Co D-42781, of mesh-size lower than $0.5 \mathrm{~mm}$ : the big particles were eliminated. The different fractions of flours obtained were weighed using a SARTORIUS balance, type 126400 with precision of $0.01 \mathrm{~g}$. All the flours were used directly for biological assays.

\section{Insect used for the bioassays}

The red flour weevil Tribolium castaneum was used at adult stage. For the experiment, adults of $T$. castaneum used were one week old. They were obtained from Unity of Entomological Researches permanent rearing kept in the dark in incubators at $27 \pm 2.1^{\circ} \mathrm{C}$ and $70 \pm 4.5 \%$ r.h. T. castaneum was kept on flour of sorghum mixed with yeast $(10: 1, w: w)$. Before being tested, these insects were starved for a 24 hours period.

\section{Insecticidal efficiency of the four flours of seeds of leguminous crops}

The formulations tested were prepared by mixing the flours of the insecticidal legume grains at a proportion which ranged from $0 \mathrm{~g}$ to $100 \mathrm{~g}$ by a step of $20(0 \mathrm{~g}, 20 \mathrm{~g}, 40 \mathrm{~g}$, $60 \mathrm{~g}, 80 \mathrm{~g}$ and $100 \mathrm{~g}$ ) and were supplemented by sorghum flour (Sorghum bicolor) in opposite direction $(100 \mathrm{~g}, 80 \mathrm{~g}, 60 \mathrm{~g}, 40 \mathrm{~g}, 20 \mathrm{~g}$ and $0 \mathrm{~g})$ so that each pot had a total content of $100 \mathrm{~g}$. The content of each pot was homogenized by stirring it 20 times using a spatula. The pots that contain only the sorghum flours constitute the control. Into each treatment 10 couples of $T$. castaneum one week old were introduced. For each preparation, 5 replications were made. 50 days after the application, all the pots were checked; the number of different stages of $T$. castaneum that are larvae III, larvae IV, larvae V, nymphs and imagoes were counted. 


\section{Statistical analysis}

Data on the mean number of stages of development of this insect considered were subjected to one-way variant analysis (ANOVA I) in the aim to determine the most insecticidal legume flour. To complete this analysis, the Duncan's multiple range test (DMRT) was used to group together the mean values that are not significantly different for each stage of development.

\section{RESULTS}

\section{Insecticidal activity of flours of the seeds of four leguminous crops on Tribolium castaneum}

Table 1 presents the effect of flours from the seeds of four edible leguminous crops used against the imagoes of $T$. castaneum. The flours of pea and black bean were the most active leguminous crops on T. castaneum. All the flours tested do not have same level of toxicity towards the red flour weevils. ANOVA I shows highly significant difference $\left(\mathrm{F}=33.78^{* * *}\right.$, df $\left.=3: 496, \mathrm{p} \leq 0.001\right)$ between the four leguminous flours. Duncan' test shows there is no significant difference between efficacies of flours of pea $(21.17 \pm 10.5)$ and black bean $(32.38 \pm 18.3)$ on $T$. castaneum $(\mathrm{p} \leq 0.01)$. The soybeans' flours were not very active, but there is the highly significant difference between SJ320 and DOCKO soybeans.

\section{Dynamic of larval populations of Tribolium castaneum 50 days after application in the different formulations}

Table 2 presents the numbers of the larvae III, larvae IV and larvae V of $T$. castaneum present in each formulation made 50 days after application.

The number of the larval populations depends on treatments applied. Concerning larvae III, the treatments DK60, DK40, SJ60, SJ40, PP40 and BB20 did not differ significantly from the control treatment (table 2). The treatment BB40 which contained more larvae III $(114 \pm 7.9)$ was significantly different from the control $(80.4 \pm 12)$. The treatments DK20 $(36 \pm 8.7)$ and SJ20 (38.8 \pm 11.9$)$ seemed most effective compared to the control. ANOVA I shows highly significant difference $(\mathrm{F}=68.532 * * *, \mathrm{df}=20: 84, \mathrm{p} \leq 0.001)$ between the control and the other treatments of leguminous flours on the one hand and between the treatments of four leguminous flours on the other hand.

For larvae IV, it arises that all the treatments of leguminous plants was significantly different from the control. The treatment SJ40 contained more larvae IV $(133 \pm 14.2)$ than the control (117.8 \pm 8.7$)$. Treatments PP20 (56.6 \pm 9.3$)$, DK20 (56.6 \pm 10.6$)$ and SJ20 (69.6 \pm 9.3$)$ were the most effective treatments. There is a highly significant difference $\left(\mathrm{F}=127.668^{* * *}, \mathrm{df}=20: 84, \mathrm{p} \leq 0.001\right)$ between the control and the others on one hand and between treatments of the four leguminous flour on the other hand. 
Concerning larvae V, ANOVA I shows highly significant difference $(\mathrm{F}=122.605 * * *$, $\mathrm{df}=20: 84, \mathrm{p} \leq 0.001$ ) between the control and the other treatments of leguminous flours on the one hand and between the treatments of four leguminous plants on the other hand. The dynamic of the population of the larvae $\mathrm{V}$ was function of the treatments. All the treatments of leguminous plants are significantly different from the control.

\section{Numbers of nymphs and adults of Tribolium castaneum present 50 days after application in the different formulations}

The number of the nymphs and the adults of T. castaneum 50 days after application in each formulation is recorded in table 3 . The number of nymphs and adults depends on treatments applied. As far as nymphs are concerned, there was a high significant difference between the number of nymphs $\left(\mathrm{F}=191.688^{* * *}\right.$, df $\left.=20: 84, \mathrm{p} \leq 0.001\right)$ when compared to the control and the other treatments of leguminous plants (Table 3). All in all, the dynamic of the population of the nymphs is function of the treatments applied. There is no significant difference between the control and treatment DK60. Furthermore, the treatments SJ20, SJ40, DK20 and DK40 although significantly different from the control had more nymphs than this last. The treatments PP20 and BB20 were not significantly different to control.

There was a high significant difference between the number of imagoes $(\mathrm{F}=$ $259.989 * * *$, df $=20: 84, \mathrm{p} \leq 0.001$ ) when compared to the control and the other treatments of leguminous plants. Finally, the dynamic of the population of the young adults is a function of the treatments applied. The treatments SJ100, SJ80, SJ60, PP60, PP40, PP20, BB60, BB40, BB20 and the control set up a homogeneous group. Treatments DK20, DK40, DK60, DK80, SJ20 and SJ40 constitute a good substrate for the full growth of this insect pest. Compared to the control, the size of the populations of the nymphs and imagoes is very significant in treatments SJ20, SJ40, DK20, DK40 and DK60.

The black bean and pea flours could not be edible resources for the development of $T$. castaneum; for the flours of soybean SJ320 and DOCKO, the treatments $20 \%$ and $40 \%$ concentration of soybean flour constitute a favorable substrate for a good growth of red flour weevils (Tables 2, 3)..

Pea and black bean flours are the most active on $T$. castaneum; at the $20 \%$ concentration, they exhibit important pest mortality; soybean flour is efficient only at high doses of more than $60 \%$.

\section{DISCUSSION}

The use of synthetic insecticides poses to human health and their environment problems of persistence and undesirable effects on non-target organism and the insect 


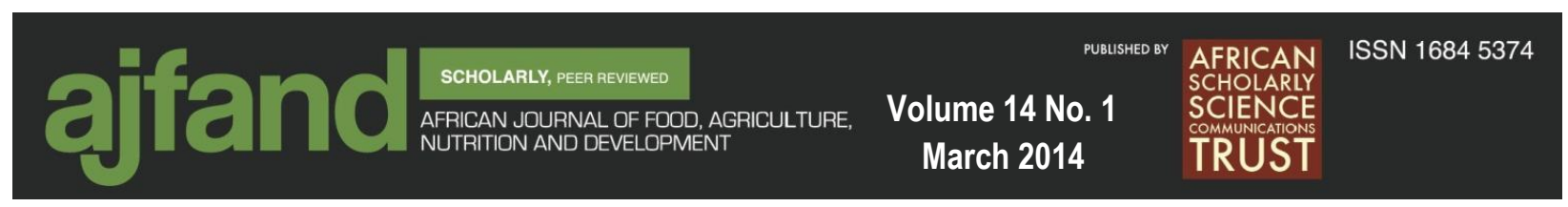

pest the phenomenon of resistance. Nowadays, many researches demonstrate the value of utilization of natural products as the safe alternatives to replace chemical pesticides to control storage pest. Chemical insecticides cannot be used in association with flour or sources of provender because of their direct consumption by humans or animals. The bioassays carry out in this study were principally experimental and are focused on important pests of stored flours and provender, the Tribolium species. Now, few studies on the preservation of flour or provender against $T$. castaneum are available, and these aliments are the principal source of nutrients for this pest and their larvae.

The utilization of flours of seeds of leguminous crops as protectant for stored cereals for human and animal consumption is important as an alternative to chemical pesticide. The fact that the seeds of theses leguminous crops are eaten by the humans and the animals indicate safety and potential contribution in protection against attack of Tribolium species.

The difference of efficacy observed between the four leguminous flours (Table 1) must be linked to their botanical group; indeed, the 4 legumes tested belong to 2 tribes: tribe of Viciea for pea and tribe of Phaseolea for bean and soybean and their chemical constituents [18]. The bean flour and the pea flour can be considered in the control of the red weevil of flour T. castaneum.

In the pea, the entomotoxic protein is called albumin PAb1 [18]; there is also a lectin PSA [20, 21, 22, 23, 24]; in bean, the entomotoxic factor is arcelin and lectin PHA [8, $24,25,26]$. The presence of homologues of PAb1 in the seeds of bean and soybean has been mentioned; the chemical constituents of many legumes among which pea, bean and soybean in their biochemical constituents also [18].

The reduced number of the individuals by stage of development in the treatments containing bean and pea (Tables 2,3) could be explained by the presence of entomotoxic substances in the seeds which limit consumption of food and thereby, the development of the insect. Indeed, the presence of PHA that is the lectin N-acetyl-Dgalactosamine specific in the bean's seed [24]; the pest of millet died quickly after feeding on pea $[24,25]$. The other entomotoxic factors that are present in the seeds of pea and bean are the albumin called PAb 1, the pisatine of pea and the phaseolline of bean $[8,25,26]$. The black bean flour introduced into the millet's flour has inhibited the development of the red weevil of flour and S. oryzae [27, 28].

The weak number of larvae III and IV in the treatments SJ20 and DK20 (Table 2) could be explained by the passage of this stage to the stages more advanced precisely the nymphs and imagoes that are so much in these treatments. The high number of the nymphs and imagoes in the treatments SJ20 (245.6 $\pm 32.4 \& 170.6 \pm 7.3)$ and DK20 (191.2 $\pm 14.3 \& 428.2 \pm 26.4$ ) (Table 3$)$ respectively could be explained by the full growing of the larvae in these biotope of life; this is justified by a significant reduced 


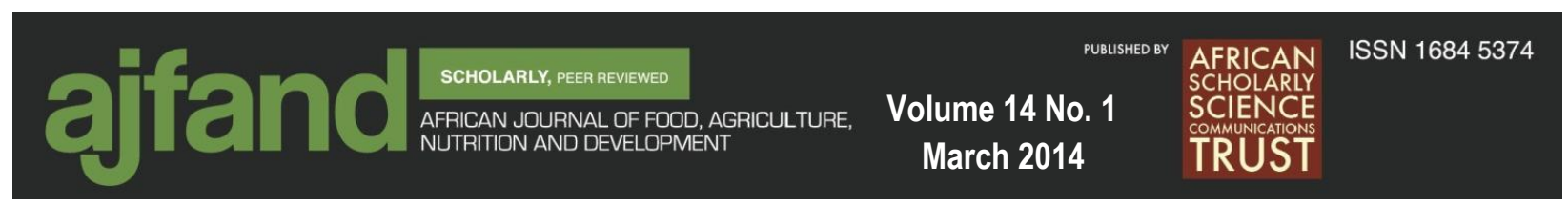

number of larvae III and IV related to the passage of the young larvae towards the more advanced stages (Table 2).

The similar results have been shown by previous works $[18,25,29]$. The special protein called arcelin present in the seeds of certain varieties of bean confers their resistance to bruchidae; this entomotoxic factor prevents the development of larvae [29]. That is why small quantity of the soybean flour in the sorghum flour is not toxic to this pest; but it is effective in the control of $S$. oryzae [18]. PA1b is the entomotoxic protein that presents a homology with lingisuline of soybean [30]. The variability of entomotoxic protein within the leguminous plants could explain also the origin of the variability of entomotoxic effectiveness of seeds of species of this group [18, 30].

The taxonomy, the chemical and biochemical constituents of these leguminous plants explain clearly the difference of toxicity observed [18, 27, 28]. The inhibition of development could be the effect of many others compounds various entomotoxic proteins different to Albumin PA1b [30].

In pest management strategies, edible legume with entomotoxic proteins efficiency should be considered. The flours of black bean and pea can be used to protect provender or flour from attacks of $T$. castaneum. Consequently, the damages of pest on flour or provender could be alleviated. Because of the relatively high quantities of the flour of soybean required to ensure the protection of the flours against this depredator, it seems difficult to consider this leguminous plant in the protection of provender.

\section{CONCLUSION}

With the dominance of synthetic pesticides capable of poisoning humans and animals, polluting water and environment, enhancing pest resistance, environmental persistence and effect on non-target species, the search of alternative methods for the protection of stored products against insects is imperative. The edible legumes are well known by the population and can be welcomed as natural insecticides because of their insecticidal properties on some insect pests during storage and preserve the environment against pollution and the consumer against chemical insecticides. The flours of four leguminous plants have insecticidal capacities on T. castaneum. The flours of black bean and pea are most efficient on this pest; these flours could be built-in in a proportion of $20 \%$ during the manufacture of provender in order to ensure its protection against this insect pest. As for the flours of two other leguminous plants, it appears that the introduction of the small fractions of soybean into the flour of millet ensures a good blooming of $T$. castaneum. For a better control of these pests, an integrated approach in killing them by flour of edible leguminous seeds preserves the natural enemies of the concerned pests such as parasitoids or predators occurring in stored foodstuff, and the environment. 
Table 1: Toxicity of 4 flour's leguminous plants food on Tribolium castaneum

Pea $\quad$ Black bean $\quad$ Soybean SJ $320 \quad$ Soybean Docko

\begin{tabular}{lllll}
\hline Means of individuals & $21.17 \pm 10.5^{\mathrm{a}}$ & $32.38 \pm 18.3^{\mathrm{a}}$ & $65.99 \pm 28.1^{\mathrm{b}}$ & $95.2 \pm 36.7^{\mathrm{c}}$
\end{tabular}

Values followed by the same letter do not differ significantly, $F=33.78$, $d f=3 ; 496 ; p \leq 0.001$ 


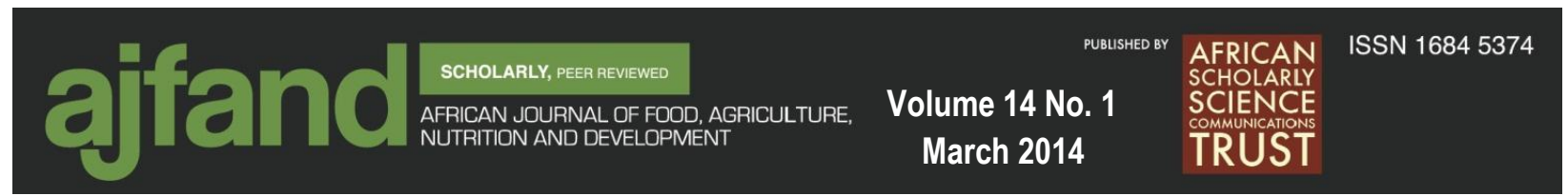

Table 2: Numbers of larvae III, larvae IV and larvae $V$ of Tribolium castaneum present in each formulation 50 days after application

\begin{tabular}{llll}
\hline & Larvae III & Larvae IV & Larvae V \\
\hline Control & $80.4 \pm 12^{\mathrm{hi}}$ & $117.8 \pm 8.7^{\mathrm{f}}$ & $142 \pm 12.5^{\mathrm{h}}$ \\
BB20 & $81.6 \pm 9^{\mathrm{i}}$ & $95.2 \pm 3.3^{\mathrm{e}}$ & $68.8 \pm 8.9^{\mathrm{f}}$ \\
BB40 & $114 \pm 7.9^{\mathrm{j}}$ & $76.4 \pm 3.5^{\mathrm{cd}}$ & $37.8 \pm 4^{\mathrm{c}}$ \\
BB60 & $53.4 \pm 2.7^{\mathrm{f}}$ & $47.6 \pm 6.7^{\mathrm{b}}$ & $11.2 \pm 4^{\mathrm{a}}$ \\
BB80 & $18.4 \pm 5.4^{\mathrm{bc}}$ & $6.8 \pm 1.6^{\mathrm{a}}$ & $0 \pm 0^{\mathrm{a}}$ \\
BB100 & $0 \pm 0^{\mathrm{a}}$ & $0 \pm 0^{\mathrm{a}}$ & $0 \pm 0^{\mathrm{a}}$ \\
\hline PP20 & $51.2 \pm 7.2^{\mathrm{ef}}$ & $56.6 \pm 9.3^{\mathrm{b}}$ & $22.2 \pm 9.9^{\mathrm{b}}$ \\
PP40 & $72.6 \pm 9.1^{\mathrm{hi}}$ & $54.4 \pm 19^{\mathrm{b}}$ & $22 \pm 9.1^{\mathrm{b}}$ \\
PP60 & $23.6 \pm 3.8^{\mathrm{c}}$ & $10.2 \pm 5.1^{\mathrm{a}}$ & $2.8 \pm 1.3^{\mathrm{a}}$ \\
PP80 & $3.2 \pm 1.5^{\mathrm{a}}$ & $1.2 \pm 0.4^{\mathrm{a}}$ & $0 \pm 0^{\mathrm{a}}$ \\
PP100 & $0 \pm 0^{\mathrm{a}}$ & $0 \pm 0^{\mathrm{a}}$ & $0 \pm 0^{\mathrm{a}}$ \\
\hline SJ20 & $38.8 \pm 11.9^{\mathrm{d}}$ & $69.6 \pm 9.3^{\mathrm{c}}$ & $64.6 \pm 9.3^{\mathrm{ef}}$ \\
SJ40 & $75.6 \pm 17.5^{\mathrm{hi}}$ & $133 \pm 14.2^{\mathrm{g}}$ & $55.2 \pm 7.6^{\mathrm{de}}$ \\
SJ60 & $82.2 \pm 12.7^{\mathrm{i}}$ & $99.2 \pm 5.2^{\mathrm{e}}$ & $45.4 \pm 2.7^{\mathrm{cd}}$ \\
SJ80 & $59.8 \pm 11.3^{\mathrm{fg}}$ & $56 \pm 6.7^{\mathrm{b}}$ & $09 \pm 3.2^{\mathrm{a}}$ \\
SJ100 & $0 \pm 0^{\mathrm{a}}$ & $0 \pm 0^{\mathrm{a}}$ & $0 \pm 0^{\mathrm{a}}$ \\
\hline DK20 & $36 \pm 8.7^{\mathrm{d}}$ & $56.6 \pm 10.6^{\mathrm{b}}$ & $87 \pm 11^{\mathrm{g}}$ \\
DK40 & $82.6 \pm 8.4^{\mathrm{i}}$ & $102.6 \pm 15^{\mathrm{e}}$ & $44.2 \pm 6.8^{\mathrm{c}}$ \\
DK60 & $69.4 \pm 16.2^{\mathrm{gh}}$ & $83.2 \pm 6.1^{\mathrm{d}}$ & $47.4 \pm 12.6^{\mathrm{cd}}$ \\
DK80 & $41 \pm 9.4^{\mathrm{de}}$ & $57.6 \pm 6.1^{\mathrm{b}}$ & $54.8 \pm 13.6^{\mathrm{de}}$ \\
DK100 & $0 \pm 0^{\mathrm{a}}$ & $0 \pm 0^{\mathrm{a}}$ & $0 \pm 0^{\mathrm{a}}$ \\
\hline Fisher & $68.532^{* * *}$ & $127.668^{* * *}$ & $122.605^{* * *}$ \\
\hline In & & & \\
\hline
\end{tabular}

In the same column, the affected values of the same letter are not significantly different ( $\mathrm{p} \leq$ $0.01)$.

\section{Legend}

$\mathrm{BB}=\mathrm{Black}$ Bean$; \mathrm{PP}=\mathrm{Pea} ; \mathrm{SJ}=\mathrm{SJ} 320$ soybean, $\mathrm{DK}=\mathrm{DOCKO}$ soybean

BB $(20,40,60,80$ and 100): treatments with black bean flour at $20 \%, 40 \%, 60 \%, 80 \%$ and $100 \%$.

PP (20, 40, 60, 80 and 100): treatments with pea flour at $20 \%, 40 \%, 60 \%, 80 \%$ and $100 \%$.

SJ (20, 40, 60, 80 and 100): treatments with SJ320 soybean flour at 20\%, 40\%, 60\%, 80\% and $100 \%$. DK (20, 40, 60, 80 and 100): treatments with DOCKO soybean flour at 20\%, 40\%, $60 \%, 80 \%$ and $100 \%$. 


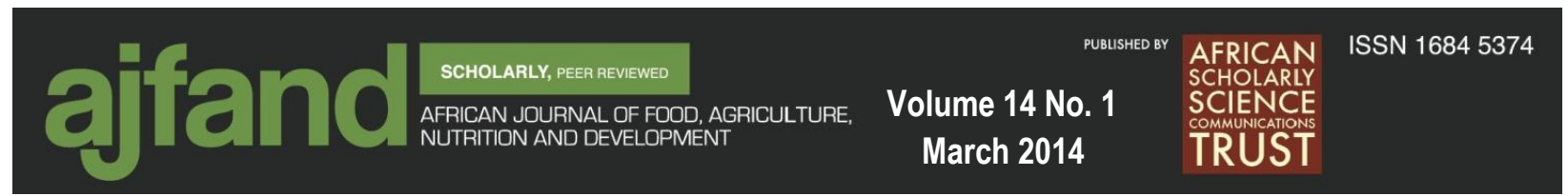

Table 3: Numbers of nymphs and adults of Tribolium castaneum present in each formulation 50 days after application

\begin{tabular}{|c|c|c|}
\hline & Nymphs & Imagoes \\
\hline Control & $143.6 \pm 7.4^{\mathrm{d}}$ & $31.2 \pm 4.8^{\mathrm{c}}$ \\
\hline BB20 & $86.6 \pm 2.7^{c}$ & $30.2 \pm 4.5^{\mathrm{c}}$ \\
\hline BB40 & $24.4 \pm 6.4^{b}$ & $18 \pm 2.4^{\mathrm{abc}}$ \\
\hline BB60 & $12.2 \pm 1.9^{\mathrm{ab}}$ & $16.8 \pm 2.6^{\mathrm{abc}}$ \\
\hline BB80 & $0 \pm 0^{\mathrm{a}}$ & $7.8 \pm 2.8^{\mathrm{ab}}$ \\
\hline BB100 & $0 \pm 0^{\mathrm{a}}$ & $0 \pm 0^{\mathrm{a}}$ \\
\hline PP20 & $82.4 \pm 6.7^{c}$ & $28.4 \pm 1.7^{\mathrm{bc}}$ \\
\hline PP40 & $31.2 \pm 10.7^{\mathrm{b}}$ & $17.6 \pm 2.6^{\mathrm{abc}}$ \\
\hline PP60 & $4.2 \pm 1.8^{\mathrm{a}}$ & $14.4 \pm 1.8^{\mathrm{abc}}$ \\
\hline PP80 & $0 \pm 0^{\mathrm{a}}$ & $8 \pm 2.8^{\mathrm{ab}}$ \\
\hline PP100 & $0 \pm 0^{\mathrm{a}}$ & $0 \pm 0^{\mathrm{a}}$ \\
\hline SJ20 & $245.6 \pm 32.4^{\mathrm{g}}$ & $170.6 \pm 7.3^{\mathrm{g}}$ \\
\hline SJ40 & $215 \pm 33.1^{\mathrm{f}}$ & $64.4 \pm 9.4^{\mathrm{d}}$ \\
\hline SJ60 & $83.4 \pm 11.1^{\mathrm{c}}$ & $25 \pm 2.5^{b c}$ \\
\hline SJ80 & $23.2 \pm 6.2^{\mathrm{ab}}$ & $18 \pm 1.9^{a b c}$ \\
\hline SJ100 & $0 \pm 0^{\mathrm{a}}$ & $0 \pm 0^{\mathrm{a}}$ \\
\hline DK20 & $191.2 \pm 14.3^{\mathrm{e}}$ & $428.2 \pm 26.4^{\mathrm{e}}$ \\
\hline DK40 & $193.2 \pm 15.2^{\mathrm{e}}$ & $350.6 \pm 63.5^{f}$ \\
\hline DK60 & $149.4 \pm 11.8^{\mathrm{d}}$ & $128.4 \pm 16.8^{\mathrm{h}}$ \\
\hline DK80 & $101 \pm 20.2^{c}$ & $58.2 \pm 10.1^{\mathrm{d}}$ \\
\hline DK100 & $0 \pm 0^{\mathrm{a}}$ & $0 \pm 0^{\mathrm{a}}$ \\
\hline Fisher & $191.688^{* * *}$ & $259.989^{* * *}$ \\
\hline
\end{tabular}

In the same column, the affected values of the same letter are not significantly different ( $\mathrm{p} \leq$ $0.01)$.

Legend

$\mathrm{BB}=$ Black Bean; $\mathrm{PP}=\mathrm{Pea} ; \mathrm{SJ}=\mathrm{SJ} 320$ soybean, $\mathrm{DK}=\mathrm{DOCKO}$ soybean

BB $(20,40,60,80$ and 100): treatments with black bean flour at $20 \%, 40 \%, 60 \%, 80 \%$ and $100 \%$.

PP (20, 40, 60, 80 and 100): treatments with pea flour at $20 \%, 40 \%, 60 \%, 80 \%$ and $100 \%$.

SJ (20, 40, 60, 80 and 100): treatments with SJ320 soybean flour at 20\%, 40\%, 60\%, $80 \%$ and $100 \%$. DK (20, 40, 60, 80 and 100): treatments with DOCKO soybean flour at $20 \%, 40 \%$, $60 \%, 80 \%$ and $100 \%$. 


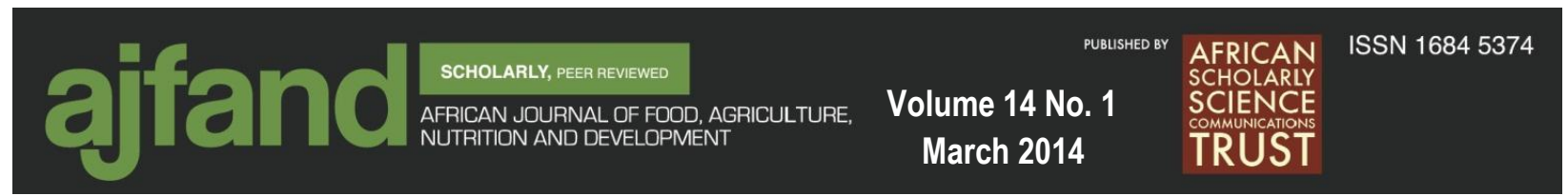

\section{REFERENCES}

1. Dal Bello G, Padin S, Lopez LC and MR Fabrizio Laboratory of evaluation Chemical-biological control of the rice weevil (Sitophilus oryzae L.) in stored grains. J. Stored Prod. Res. 2001; 37: 77-84.

2. De Luca J Impureté et souillure d'origine animale dans les denrées végétales pulvérulentes-critères-impact-détection-controle-législation-perspective. APRIA, 1979; 76p.

3. Hodges RJ, Robinson $\mathbf{R}$ and $\mathbf{P}$ Hall Quinone contamination of dehusked rice by Tribolium castaneum (Herbs) (Coleoptera: Tenebrionidae). J. Stored prod. Res. 1996; 36:107-117.

4. Fleurat-Lessard F Ecophysiologie des Arthropodes nuisibles aux stocks des céréales en Afrique tropicale. In: Post récolte principe et application en zone tropicale. ESTEM/AUPELLF. Ottawa $1994 ; 1-61$.

5. Schumutterer $\mathbf{H}$ and KRS Ascher Natural pesticides from the neem tree (Azadirachta indica A Juss) and other tropical plants. Proc 3rd Neem Conference Nairobi 1986; 517-523.

6. Ngamo Tinkeu LS Protection intégrée des stocks de céréales et de légumineuses. B.I.P. $2000 ; \mathbf{4 3}: 13$.

7. Sauvion N, Nardon C, Febvay G, Gatehouse AMR and Y Rahbe Binding of the insecticidal lectin Concanavalin A in pea aphid, Acyrthosiphon pisum (Harris) and induced effects on the structure of midgut epithelial cells. $J$. Insect Physiol. 2004; 50(12): 1137-1150.

8. Karimi $\mathbf{J}$, Haubruge $\mathbf{E}$ and $\mathbf{F}$ Francis Development of entomotoxic molecules as control agents: illustration of some protein potential uses and limits of lectins (Review), Biotechnol. Agron. Soc. Environ. 2010; 14(1): 225241.

9. Conner AJ, Glare TR and JP Nap The release of genetically modified crops into the environment-Part II. Overview of ecological risk assessment. Plant J. 2003; 33(1): 19-46.

10. Majumder P, Mondal $\mathbf{H A}$ and $\mathbf{S}$ Das Insecticidal activity of Arum maculatum tuber lectin and its binding to the glycosylated insect gut receptors. J. Agric. Food Chem. 2005; 53(17): 6725-6729.

11. Macedo MLR, Freire MGM, Silva MBR and LCBB Coelho Insecticidal action of Bauhinia monandra leaf lectin (BmoLL) against Anagasta kuehniella (Lepidoptera: Pyralidae), Zabrotes subfasciatus and Callosobruchus maculatus (Coleoptera: Bruchidae). Comp. Biochem. Physiol. 2006; 146: 486-498. 
12. Aronson AI Bacillus thuringiensis and its use as a biological insecticide. In: Janick J., ed. Plant Breeding Reviews. New York, USA: Wiley, 1994; 19-45.

13. Bandyopadhyay S, Roy A and S Das Binding of garlic (Allium sativum) leaf lectin to the gut receptors of homopteran pests is correlated to its insecticidal activity. Plant Sci. 2001; 61(5): 1025-1033.

14. Carlini CR and MF Grossi-de-Sa Plant toxic proteins with insecticidal properties: a review on their potentialities as bio-insecticides. Toxicon. 2002; 40(11): 1515-1539.

15. Wang G, Zhang J, Song F, Wu J, Feng $S$ and D Huang Engineered Bacillus thuringiensis G033A with broad insecticidal activity against lepidopteran and coleopteran pests. Appl. Microbiol. Biotechnol. 2006; 72(5): 924-930.

16. Ferre $\mathbf{J}$ and $\mathbf{J V}$ Rie Biochemistry and genetics of insect resistance to Bacillus thuringiensis. Ann. Rev. Entomol. 2006; 47: 501-533.

17. Janmaat AF and $\mathbf{J}$ Myers Rapid evolution and the cost of resistance to Bacillus thuringiensis in greenhouse populations of cabbage loopers, Trichoplusia ni. Proc. R. Soc. London Ser. B Biol. Sci. 2003; 270: 2263-2270.

18. Louis $\mathbf{S}$ Diversité structurale et d'activité biologique des albumines entomotoxiques de type $1 \mathrm{~b}$ des graines de légumineuses. Thèse de Doctorat, I.N.S.A. Lyon. 2004; 260.

19. Hirsh AM Role of lectins (and rhizobial exopolysaccharides) in legume nodulation. Curr. Opin. Plant. Biol. 1991; 4: 230-326.

20. Osborn TC, Alexander DC, Sun SS, Cardona C and FA Bliss Insecticidal activity and lectin homology of arcelin seed protein. Science. 1988; 207p.

21. Iulek J, Franco OL, Silva M, Slivinski CT, Bloch C, Rigden DJ and MF Grossi-de-sa Purification, biochemical characterisation and partial primary structure of a new alpha-amylase inhibitor from cereal (rye). Int. J. Biochem. Cel. Phy. 2000; 32: 1195-1204.

22. Grossi De Sa MF, Mukov TE, Ishimoto M, Colucci G, Bateman KS and MJ Chrispeels Molecular characterisation of a bean alpha-amylase of the mexican bean weevil Zabrotes subfasciatus. Planta. 1997; 203: 295-303.

23. Rahbé Y, Sauvion N, Febvay G, Peumans W J and AMR Gatehouse Toxicity of lectins and processing of ingested proteins in the pea aphid Acyrthosiphon pisum. Entomol. Exp. Appl. 1995; 76: 143-155. 
24. Elden TC Influence of a cysteine proteinase inhibitor on alfafa weevil (Coleptera: Curculionidae) growth and development over successive generations. J. Entomol. Sci. 2000; 35: 70-76.

25. Higgins TJV, Chandler TE, Randall PJ, Spencer D, Beach RL, Blogrove RJ, Kortt AA and AS Inglis Gene structure, protein structure and regulation of the synthesis of sulphur rich protein in pea seeds. J. Biol. Chem. 1986; 261: 11124-11130.

26. Habibi JE, Backus EA and JE Huesing Effects of phytohemagglutinin (PHA) on the structure of midgut epithelial cells and localization of its binding sites in western tarnished plant bug Lygus hesperus Knight. J. Insect Physiol. $2000 ; \mathbf{4 6}(\mathbf{5})$ : 611-619.

27. Tamgno BR Activité insecticide d'une formulation poudreuse à base de la farine de Phaseolus vulgaris (L.) sur Sitophilus oryzae (L.) (Coleoptera: Curculionidae). D.E.A., Dép. B.P.A.Université de Yaoundé I. 2009; 54p.

28. Fatimé AA Amélioration de la conservation de la farine de sorgho par l'incorporation des huiles essentielles et de la farine de deux légumineuses alimentaires. Mémoire de DEA, ENSAI Université de Ngaoundéré. 2007; 94p.

29. Watanabe Y, Barbashov SF, Komatsu S, Hemmings AM, Miyagi M, Tsunasawa $\mathbf{S}$ and $\mathbf{H}$ Hirano A peptide that stimulates phosphorylationof the plant insulin-binding protein. Isolation, primary structure and cDNA cloning. Eur. J. Bchem. 1994; 224: 167-172.

30. Bisby FA, Buckingham $\mathbf{J}$ and $\mathbf{J B}$ Harborne Phytochemical dictionary of Leguminoseae. Chapman and Hall; 2000; 854p. 